\title{
Various causes related to dead-in-shell embryos of crossbred (PB-2 x I ndigenous) chicken egg
}

\author{
N. Kalita, N. Pathak, M. Ahmed and G. K. Saikia \\ All India Coordinated Research Project on Poultry Breeding, Department of Poultry Science, \\ College of Veterinary Science, Assam Agricultural University, Khanapara, Guwahati-781022, Assam, India \\ Corresponding author: N. Kalita, email: niranjankalita2004@yahoo.co.in \\ Received: 26-05-2013, Revised: 15-07-2013, Accepted: 15-07-2013, Published online: 19-08-2013
}

doi: 10.14202/vetworld.2013.774-777

How to cite this article: Kalita N, Pathak N, Ahmed M and Saikia GK (2013) Various causes related to dead-in-shell embryos of crossbred (PB-2 x Indigenous) chicken egg, Veterinary World 6(10): 774-777.

\begin{abstract}
Aim: The present study was undertaken to study the etiopathology of dead-in-shell embryos of PB-2 male x Indigenous female crossbred chicken egg.

Materials and Methods: A total of 1377 eggs were incubated which was collected from a flock of crossbreed bird (PB2xIndigenous) chicken. Out of which 568 (41.25\%) egg failed to pip out, were utilized for further study. All the dead in shell embryos were examined for different anomalies and pathological condition thorough necropsy examination. For bacteriological isolation a piece of liver, lung and yolk sac contents were collected from 25 nos. of dead in shell embryos and send to the Department of Microbiology for further examination.
\end{abstract}

Results: A total of 241 (42.42\%) egg were recorded as dead-in-shell embryos out of 568 eggs which were fail to pip out. The percentage of dead-in-shell was higher on $21^{\text {st }}$ day $(61.34 \%)$ than $18^{\text {th }}$ day $(38.66 \%)$ of incubation. Out of 241 nos. of dead in shell embryos, 47 (19.50\%) cases showed malpositions, 19 (7.88\%) malformation, 6 (2.49\%) adhesion,4 (1.66\%) dehydration, $67(27.80 \%)$ pathological condition and $98(40.66 \%)$ cases showed no definite abnormalities and $327(57.57 \%)$ numbers of egg were found as infertile.

Conclusion: The dead in shell embryo may be due to genetic factor, breed, some pathological condition, frequent power failure, lack of proper hygiene etc.

Keywords: crossbred chicken egg, dead in shell embryo, etiopathology.

\section{Introduction}

The demand of poultry and poultry products in the North East region of India is very high as majority of the people of this region are non-vegetarian and they preferred poultry meat and egg. The production of poultry meat and egg has shown an increasing trend with the introduction of improved breeds/strains of poultry. Today, the broiler sector is growing at the rate of $8-10 \%$ per annum as compared to the dairy sector which grows at the rate of 5-6 per cent per annum [1]. But the increase is not proportional to the efforts due to various set back like infectious diseases, managemental problems, hatchery problems etc. In a study [2] recorded $8.96 \%$ incidence of dead-in-shell embryos out of 48,831 incubated eggs. Available literature did not reveal much systematic works on the dead-in-shell embryos of chicken in Assam. The dead-in-shell embryos indicate the hygienic and managemental status of the hatcheries and this further leads to early chick mortality.

Therefore, a systematic study has been planned to evaluate the causes of dead-in-shell embryos of chicken egg collected from the PB-2 x Indigenous

Copyright: The authors. This article is an open access article licensed under the terms of the Creative Commons Attribution License (http://creativecommons.org/licenses/by/2.0) which permits unrestricted use, distribution and reproduction in any medium, provided the work is properly cited. crossbred chicken, being maintained at "All India Coordinated Research project (AICRP) on Poultry Breeding", Department of Poultry Science, College of Veterinary Science, Assam Agricultural University, Khanapara .

\section{Materials and Methods}

The study was conducted during the period of October, 2011 to December, 2011. In total 1377 egg were incubated which was collected from a flock of crossbreed bird (PB-2 x Indigenous) chicken being maintained at the "AICRP on Poultry Breeding", Department of Poultry Science, College of Veterinary Science, AAU, Khanapara, Guwahati-22. A total of 568 egg have been failed to pip out, of the total 1377 nos. of egg incubated were utilized for further study as stated below:

\section{Pathological study:}

Gross examination: The infertile and dead-in-shell embryos were calculated from the eggs which fail to pip out. All the dead-in-shell embryos were examined for different anomalies as well as pathological conditions through necropsy examination.

Bacteriological examination: Among the 67 dead-inshell embryos with pathological condition but without any developmental anomalies, suitable materials viz. pieces of liver, lung and yolk sac contents were 


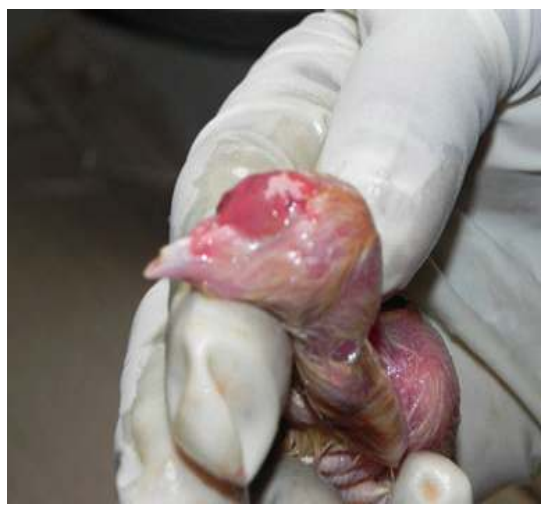

Figure-1. Photograph showing short upper beak

collected randomly in aseptic condition from 25 embryos and sent to the Department of Microbiology, College of Veterinary Science, Assam Agricultural University, Khanapara for bacteriological isolation.

Among the different factors (experimental treatments) the presumption of contribution towards the causes of dead in shell is as follows:

(1) Malformation.

(2) Pathological condition

(3) Dehydration

(4) Malposition

(5) Adhesion.

\section{Results}

A total of 1377 incubated eggs were observed, where $568(41.25 \%)$ egg failed to pip out. The hatchability of total egg set was $58.75 \%$. Out of the 568 egg, a total of $241(42.42 \%)$ egg were recorded as dead-in-shell embryos and $327(57.57 \%)$ were found infertile. The percentage of dead-in-shell embryos was higher on the $21^{\text {st }}$ day $(61.34 \%)$ than on the $18^{\text {th }}$ day $(38.66 \%)$ of incubation which have been confirmed by candling on $18^{\text {th }}$ day and by breakout open of the eggs on $22^{\text {nd }}$ day. Out of 241 dead-in-shell embryos, 47 $(19.50 \%)$ cases showed malposition, $19(7.88 \%)$ cases showed malformation, $6(2.49 \%)$ cases showed adhesion, $4(1.66 \%)$ cases showed dehydration, $67(27.80 \%)$ cases showed pathological condition and 98 (40.66\%) cases showed no definite abnormalities.

\section{Various abnormalities:}

Malposition: The different malpositions recorded were head towards the left side in 24 of embryos, head towards the small end of the egg in 19 numbers of embryos and head in between the thigh only in 4 numbers of embryos.

Malformation: In the present study only $19(7.88 \%)$ cases of malformation were recorded. The different malformations were like crossed beak, short upper beak (Fig.1), twins, abnormal legs and intestinal prolapse.

Dehydration and adhesion: In the study 4 cases of dehydration (Fig.2) and 6 cases of adhesion were recorded.

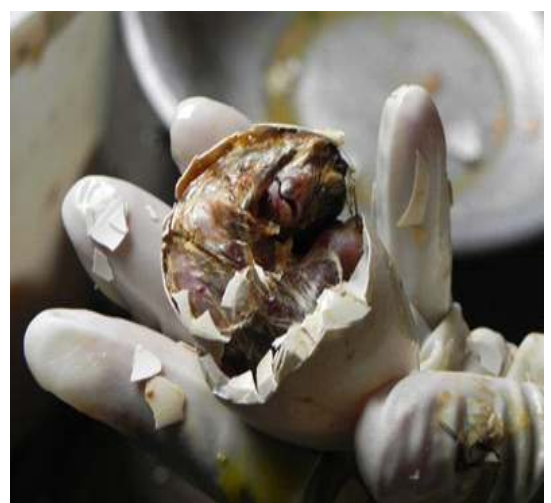

Figure-2. Photograph showing dehydrated dead-in-shell embryos

Bacterial disease: Among the 67 dead-in-shell embryos having pathological condition, 25 dead-inshell embryos were sent for cultural examination from which 17 embryos showed septicemia. The organisms isolated from such embryos were Streptococcus species, Staphylococcus species and Escherichia coli.

Gross lesion: The visceral organs viz. heart, liver, lungs, kidneys and intestine showed marked congestion. The yolk content was found discolored and most of the liver showed whitish yellow discoloration.

Undiagnosed: Out of 568 dead-in-shell embryos, 98 were undiagnosed.

\section{Discussion}

The total hatchability was $58.75 \%$. The present value was lower than the values reported by earlier workers [3-6]. The dead-in-shell embryo was found higher on the $21^{\text {st }}$ day than on the $18^{\text {th }}$ day of incubation which was in agreement with findings of [2,7]. This value was higher than the value reported by Singh [8]. The higher incidence of mortality on $21^{\text {st }}$ day might be due to the malpositions that were recorded mostly on the $21^{\text {st }}$ day of incubation [9]. Malpositions with varied incidence were also recorded by the earlier workers $[2$, 10-16]. The incidence of malpositions is increased in summer season [17]. Development of malpositions might be due to genetic factors, position of eggs in the incubation tray, ambient temperature, age and size of the eggs, breed, individual difference and presumably many other factors as opined by Landaur $[13,14,18]$. The quality of chicks that emerges out of an egg depends on some factors such as the age of the breeder, length and storage conditions of egg before incubation and the incubation conditions [19,20]. Goswami [2] recorded only $0.15 \%$ malformation from his study. Low incidence of malformation might be due to better selection of parent stocks and hatchery management as these play an important role in the incidence of malformations of embryo [21]. The incomplete healing of umbilical mostly occurs due to defective incubator with reduced air flow, temperature, dry cooling system, increased relative humidity etc. [22]. Goswami [2, 13] in his study recorded dehydration and adhesion in 
different numbers. Various organisms like Streptococcus, Staphylococcus and Escherichia coli spp. etc. were also isolated from dead-in-shell embryos by various workers [23-28]. Fecal contamination of egg shell, design and ventilation of hatchery, stocking density, poor sanitation of hatchery room and their equipments may causes poor hatchability and dead in shell embryo $[25,29]$. Undiagnosed embryos did not show any developmental anomalies as well as pathological condition which might be due to various other causes like viral diseases, inbreeding or the eggs might be from carrier birds of various diseases which needs further investigation. Frequent power failure, mechanical defect of incubator and voltage fluctuation during incubation period may be considered one of the reason of this incidence [30]. Goswami [2] also recorded a higher percentage of dead-in-shell embryos without any abnormalities.

From the above observation it is seen that the important factors among different treatment for causes of dead in shell are pathological condition, malpositions, malformation, adhesion and dehydration in addition to the undefined abnormalities.

\section{Conclusion}

The dead-in-shell embryo of crossbred chicken egg may be due to genetic factor, ambient temperature, breed, individual difference, some pathological condition, frequent power failure, lack of proper hygiene and sanitation in the hatchery room and equipments etc.

\section{Authors' contributions}

NK, NP, MA: Acquisition of data, drafting and revision of the article, substantial contribution to conception and design, NP: Pathological work, GKS: Bacteriological work. All authors read and approved the final manuscript.

\section{Acknowledgements}

The authors are grateful to Indian Council of Agricultural Research, New Delhi, India for providing necessary fund in time to carry out the research. The authors are also thankful to the Director of Research, Veterinary, AAU, Khanapara, Guwahati-22 for providing the necessary facilities.

\section{Competing interests}

The authors declare that they have no competing interests.

\section{References}

1. Haleem, M.A. (2009) Panel discussion on meat and poultry global trends challenges and their redresses. Poult. Planner (Supplementary Issue) - ILDEX India 2009.11(4):8.

2. Goswami, J. (2009) Etiopathology of mortality in broiler chicks. M.V.Sc. Thesis submitted to Assam Agricultural University, Khanapara, Guwahati, India.

3. Schaal, T. and Cherian, G.(2007) A survey of the hatchability of broiler and turkey eggs in the United States from 1985 through 2005. Poult. Sci.86:598-600.

4. Sankhyan, V., Katoch, S., Thakur, Y.P., Dogra, P.K. and Bhardwaj, N. (2012) Non- genetic factors affecting fertility, hatchability and chick survivability in sub temperate
Palampur region of Himachal Pradesh. Proceed. of XXIX Anl. Conf. and Natnl. Symp. of Ind. Poult. Sci. Assoc.. 5-7 December, Rajendranagar, Hyderabad, Ind., pp.17 (Abstr.).

5. Henry, A.C.E., Jagatheesan, P.N.R., Paramasivam, A. and Mehala, C. (2012) Fertility and hatchability of Nandanam-I, Nandanam-II and desi varities of turkey. Proceed. of XXIX Anl. Conf. and Natnl. Symp. of Ind. Poult. Sci. Assoc.. 5-7 December, Rajendranagar, Hyderabad, Ind., pp.9 (Abstr.).

6. Rajkumar, U., Niranjan, M., Rajarabindra, K.S., Padhi, M.K., Bhattacharya, T.K. and Chatterjee, R.N. (2012) Evaluation of juvenile and production performance in Grampriya male line chicken. Proceed. of XXIX Anl. Conf. and Natnl. Symp. of Ind. Poult. Sci. Assoc.. 5-7 December, Rajendranagar, Hyderabad, India, pp.7 (Abstr.).

7. Tona, K., Bamelis, F., Coucke, W., Bruggeman, V. and Decuypere, E. (2001) Relationship between broiler breeders's age and egg weight loss and embryonic mortality during incubation in large scale conditions. J. App. Poult. Res. 10:221-227.

8. Singh, D., Reddy, B.L.N. and Bhanja, S.K. (2012) Studies on incubation parameters in coloured broiler (PB-I) population over generations. Proceed. of XXIX Anl. Conf. and Natnl. Symp. of Ind. Poult. Sci. Assoc.. 5-7 December, Rajendranagar, Hyderabad, Ind., pp.225 (Abstr.).

9. Sanctuary, W.C. (1925) One cause of dead in chick in shell. Poult. Sci. 4:141-153.

10. Amer, M.F. (1962) Embryonic mortality and malpositions in Fayoumi chicken. Poult. Sci. 41:1702-1712.

11. Rudraprasad, V.C., Vijayasarathi, S.K. and Sreenivas, G.R.N.(1996) Malpositions in dead-in-shell chicken embryos. Indian J. Poult. Sci.31 (1):56-59.

12. Wilson, H.R., Neuman, S.L., Eldred, A.R. and Mather, F.B. (2003) Embryonic Malpositions in Broiler Chickens and Bobwhite Quail. J. App. Poult. Res. 12:14-23.

13. Sharaf, M.M., Taha, A.E. and Ahmed, N.A.E. (2010) Deformities and abnormalities of Egyptian chicken embryos as reason of poor hatchability percentages. Egypt. Poult. Sci.30(1):317-337.

14. Kalita, N., Barua, N., Pathak, N. and Islam, R. (2011) Etiopathology of dead in shell embryos of indigenous chicken egg. Indian J. Poult. Sci.46(2):275-277.

15. Kalita, N., Pathak, N., Ahmed, M. and Saikia, G.K. (2012) Various cause related to dead in shell embryos of Vanaraja and Crossbred chicken egg. Proceed. of XXIX Anl. Conf. and Natnl. Symp. of Ind. Poult. Sci. Assoc.. 5-7 December, Rajendranagar, Hyderabad, Ind., pp.133 (Abstr.).

16. Das, B.C. (1973) An investigation in to the mortality of embryos and brooder house chicks. M.V.Sc. Thesis. Orissa University of Agriculture and Technology, India.

17. Vyas, R. and Bhatnagar, D.S. (1966) Embryonic mortality and malpositions in white leghorn breeds of poultry. Indian Vet. J.43:524-533.

18. Landauer, W. (1961) The hatchability of chicken eggs as influenced by environment and heredity. Connecticut Agric. Exp. Sta. Monograph 1.(c.f.Das,1973).

19. Tona, K., Bruggeman, V., Onabgesan, O., Bamelis, F., Gbeassor, M., Mertens and Decuypere, E.(2005) Day old chick quality: Relationship to hatching egg quality, adequate incubation practice and prediction of broiler performance. Avian. and Poult. Biol. Res.16:109-119.

20. Rodriguez, B. and Juarez, L.(2008) Developmental delay and other anomalies in the offspring from hens immunized against soluble and foreign chick embryo antigen. American J. Reprd. Immunol. 60 (2):141-150.

21. Wannop, C. (1968) Some abnormalities of the chick embryo. Labortory Animal 2:191-194.

22. Borzemska, W., Piusinski, W., Malec, H. and Niedzioka, J. (1990) Pathomorphological changes in dead chick embryos from incubation at low values of cooling. Medicyna. Weterynaryjna. 46: 103-105.

23. Al-Sadi, H.I., Basher, H.A. and Ismail, H.K. (2000) Bacteriologic and pathologic studies on dead-in-shell 
embryos. Iraqi J. Vet. Sci. 13(2):297-307.

24. Raji, M., Adekeye, J., Kwaga, J., Bale, J. and Henton, M. (2007) Serovars and biochemical characterization of Escherichia coli isolated from colibacillosis cases and deadin-shell embryos in poultry in Zaria, Nigeria. Vet. Arhiv 77(6):495-505.

25. Muhammad, M., Muhammad, L.U., Mani, A.U. and Ambali, A.G.(2009) A survey of chick mortality at hatching in three selected hatcheries in Jos, central Nigeria. Int. J. Poult. Sci. 8 (7):656-659.

26. Jahantigh, M. (2010) Bacteriological study of Dead-in-Shell embryos of ostrich. Indian J. Vet. Res.11(1):88-90.
27. Mazengia, H., Alemu, S., Mekuriaw, G. and Wuletaw, Z. (2012) Embryo mortality and isolation of E. coli as cause of death for in shell chick embryos and first week chicks. American. J. Vet.Med.Res.1(2): 33-36.

28. Phangcho, C.V. and Mukit, A. (2002) Isolation of bacterial and fungal agents from dead in shell embryos of domestic pigeon (Columba livia). Indian J. Poult. Sci. 37:209-210.

29. Shane, S.(1999) Promoting chick quality and liveability. ASA. Tech. Bull. 43:1-3.

30. Das, R.K., Mishra, U.K. and Mishra, P.R. (1994) Embryonic death of chicks: a suevey. Indian Vet. J. 71:975-977.

\section{$* * * * * * * *$}

